\title{
ANALYSIS OF POLLUTED PLACES: CASE OF LAND DEGRADATION IN LATVIA
}

Velta Parsova, Department of Land Management and Geodesy, Faculty of Environment and Civil Engineering of Latvia University of Agriculture, Address: 19, Akademijas Str., Jelgava, Latvia; velta.parsova@llu.lv (corresponding author)

Anda JANKAVA, Department of Land Management and Geodesy, Faculty of Environment and Civil Engineering of Latvia University of Agriculture, Address: 19, Akademijas Str., Jelgava, Latvia; anda.jankava@1lu.lv

Maija BERZINA, Department of Land Management and Geodesy, Faculty of Environment and Civil Engineering of Latvia University of Agriculture, Address: 19, Akademijas Str., Jelgava, Latvia; maija.berzinaaa@gmail.com

\begin{abstract}
The aim of the article is to analyse and evaluate the information on polluted and potentially polluted places registered in the Register of polluted and potentially polluted places in Latvia. Under the influence of various natural conditions and economic activities land and soil degradation processes are observed, which has led to formation of degraded territories. Degraded territory is a territory with destroyed or damaged upper layer of ground or an abandoned territory of construction, extraction of mineral resources, economic or military activities, which in result of economic or other activity or inaction has so far destroyed, that is impossible to use it properly without special restoration measures. One of the factors that can be used to assess land degradation and determine the type of land degradation is pollution. In accordance with the Law "On pollution" in Latvia have been established procedures for identification of polluted places and developed criteria which are used for assessment of risk level. On this basis the Centre for Environment, Geology and Meteorology of Latvia has established and maintains the Register of polluted and potentially polluted places. The polluted place is soil, subsoil, water, sludge, as well as buildings, factories or other objects containing pollutants. Potentially polluted places can be listed according to unverified information. In 2017 in Latvia 351 polluted and 2648 potentially polluted places were listed and registered. The largest concentration of polluted places is located in Riga, which is largest industrial centre in Latvia.
\end{abstract}

Keywords: degraded territory, pollution, polluted place, potentially polluted place, restoration

\section{INTRODUCTION}

Due to various economic activities and natural conditions land and soil degradation processes are observed, which has led to formation of degraded territories. Degraded territory is a territory with destroyed or damaged upper layer of ground or an abandoned territory of construction, extraction of mineral resources, economic or military activities, which in result of economic or other activity or inaction has so far destroyed, that is impossible to use it properly without special restoration measures. On $25^{\text {th }}$ of September, 2015, the General Assembly of United Nations adopted the resolution "Transformation of our world: 2030, a Program for Sustainable Development". The resolution set 17 sustainable development goals, including economic, social and environmental dimension. One of the goals of the environmental dimension is to "regenerate degraded land and strive for achievement of neutral of land degradation world" (Transforming our world ..., 2015). This is the first global level document that provides general and comprehensive action on this issue.

Scientists of different countries in their publications have attracted considerable attention to the problems of soil and soil degradation, its impact and prevention measures (Akhtar-Schuster, et al., 2017; Hajdu, et al., 2016; Jankauskas, Jankauskiene, 2003; Juozapavičiūtè, 2016; Salvati, Carlucci, 2014).

This problem is very topical also in Latvia. Several years ago, in our country, the concept of soil and soil degradation started. Scientists already since 2000 have participated in several projects on soil degradation issues (Karklins, et al., 2016), in cooperation with foreign scientists have been developed multidisciplinary study aid (Jackson at al., 2010), have been implemented research projects on types, expressions and classification of land and soil degradation (Degradeto teritoriju izpete..., 2004, Jankava, et.al. 2017, Parsova, et.al., 2017). With regard to the risks of land degradation and their elimination in Latvia, on $1^{\text {st }}$ of January, 2015, has entered into force the Land Management Law, which defines the concept of land and soil degradation and obliges local governments to display degraded territories in spatial planning documents, while the landowner has an obligation to perform land degradation prevention measures.

So far, land degradation issues are being addressed in various expressions, adding to degraded territories an areas which are affected by different disadvantaged environmental processes and their results, such as areas polluted with waste, overgrown with invasive plants, territories of exterminated former military objects, etc. As an important factor of land degradation often is mentioned environmental pollution (Kronenberg, et al., 2017). Polluted places have a negative impact on water, soil and air. In Latvia in 2001 the Law "On Pollution" has been adopted, the aim of which is to prevent or reduce

Copyright (C) 2017 The Authors. Published by Aleksandras Stulginskis University. This is an open-access article distributed under the terms of the Creative Commons Attribution License (CC-BY 4.0), which permits unrestricted use, distribution, and reproduction in any medium, provided the original author and source are credited. 
damage to human health, property and the environment caused by pollution and to prevent the damage caused by this harm. This law defines pollution as "direct or indirect introduction, as a result of human activity, of substances, vibrations, heat or noise in the air, water or land, which may be harmful to human health or the environment and which may result in damage to material property, or interfere with the use of natural resources and other legitimate uses of the environment" (On Pollution, 2001). In order to identify the extent of pollution and its territorial location, the law established that it is necessary to create a register of polluted and potentially polluted places. Maintenance of this register is delegated to the Latvian Environment, Geology and Meteorological Centre (LEGMC). In accordance with the Law polluted place is soil, subterranean depths, water, sludge, as well as buildings, production facilities or other facilities containing polluting substances, but potentially polluted place - soil, subterranean depths, water, sludge, as well as buildings, production facilities or other facilities that according to unverified information contain or may contain polluting substances.

The identification of polluted and potentially polluted places in a campaign-oriented way in Latvia took place in 2003-2004, but information in the register is updated in accordance with the provisions of the Law "On Pollution". Basic information about polluted places is provided by the local governments to the State Environmental Service (SES). SES transfers this information further to the LEGMC, which collects and processes environmental information, conducts environmental monitoring and informs the public about the environmental situation, ensures the geological supervision of subterranean depths and its rational use, as well as implements state policy in geology, meteorology, climatology, hydrology, air quality and transboundary air pollution sphere of influence.

The aim of the article is to analyse and evaluate the information on polluted and potentially polluted places registered in the Register of polluted and potentially polluted places in Latvia.

\section{RESEARCH METHODS}

The subjects of the study are polluted and potentially polluted places as an important land degradation factor. The territories registered in the Information System of polluted and potentially polluted places maintained by the LEGMC, are divided into three categories:

- $\quad$ polluted place

- potentially polluted place

- $\quad$ place that is not potentially polluted.

The territories included in the $3^{\text {rd }}$ category cannot be considered as degraded territories, because they did not meet the definition of degraded territory. Therefore, information on places which are not potentially polluted was excluded, and for investigation purposes were selected two categories:

- $\quad$ polluted places

- $\quad$ potentially polluted places.

Within the framework of the study these two categories of polluted places were analysed separately. For each category was analysed the information available in the Register of polluted and potentially polluted places separately in cities and districts. In Latvia according to the administrative division are 9 cities of republican significance: Daugavpils, Jekabpils, Jelgava, Jurmala, Liepaja, Rezekne, Riga, Valmiera and Ventspils. The rest territory consists of 110 districts, which consist of one or more municipal territory, or one or more municipal territories and one or more district town.

Data on polluted and potentially polluted places were grouped according to the sectors of their activities, as well as to the type of ownership: state ownership, municipal ownership, ownership of natural persons or legal persons. Analysing the collected information, the abstract logical method and its techniques were used: analysis and synthesis, induction and deduction, etc.

\section{RESULTS}

As result of the research, it was found that in the Register of polluted and potentially polluted places 351 polluted place and more than 2.6 thousand potentially polluted places are registered (Table 1).

Table 1 . Number of polluted and potentially polluted places registered in the Register

\begin{tabular}{|l|l|c|c|c|}
\hline \multirow{2}{*}{ Category } & \multirow{2}{*}{ Total } & \multicolumn{2}{|c|}{ including } \\
\cline { 3 - 5 } & & 351 & cities of republican significance & districts \\
\hline 1. & Polluted place & 2648 & 395 & 124 \\
\hline 2. & Potentially polluted place & 2253 \\
\hline
\end{tabular}

Of the cities of republic significance the largest concentration of polluted and potentially polluted places is in the capital city Riga, where 82 polluted places and 141 potentially polluted places are registered, as well as Ventspils, where there are 24 polluted places and 42 potentially polluted places. In both of these cities there are located ports with corresponding spheres that facilitate environmental pollution. In turn, Riga in terms of number of residents, as well as employment opportunities, considerably exceeds any other city in Latvia. Looking to the districts, near Riga are located municipalities which are more active than other districts in different types of entrepreneurship, there is observed higher density of polluted places. In Jelgava which is located near to Riga (42 km) is only one polluted place, but is significant number (70) of potentially polluted places. Other cities have a relatively small number of polluted places, however, as a 
bad example can be mentioned Jurmala, which is located on the coast of Baltic Sea, containing 7 polluted places. It is not compatible with the status of a resort town (Table 2).

Table 2. Number and breakdown of polluted and potentially polluted places according categories in cities of republican significance

\begin{tabular}{|c|c|c|c|c|}
\hline \multirow{2}{*}{ City } & \multicolumn{2}{|c|}{ polluted places } & \multicolumn{2}{|c|}{ potentially polluted places } \\
\hline & number & $\%$ & number & $\%$ \\
\hline Daugavpils & 3 & 2.4 & 24 & 6.1 \\
\hline Jekabpils & 3 & 2.4 & 13 & 3.3 \\
\hline Jelgava & 1 & 0.8 & 70 & 17.7 \\
\hline Jurmala & 7 & 5.5 & 24 & 6.1 \\
\hline Liepaja & 3 & 2.4 & 39 & 9.9 \\
\hline Rezekne & - & - & 25 & 6.3 \\
\hline Riga & 82 & 64.5 & 141 & 35.7 \\
\hline Valmiera & 4 & 3.1 & 17 & 4.3 \\
\hline Ventspils & 24 & 18.9 & 42 & 10.6 \\
\hline Total & 127 & 100.0 & 395 & 100.0 \\
\hline
\end{tabular}

In the Register, without the name of territory, cadastral and other relevant data, also sector of activity is registered. In order to find out the main sectors of activity promoting pollution of soil and land, in the study was selected information on polluted and potentially polluted places and grouped it according sector of activity. In the future, an analysis will be carried out separately for polluted and potentially polluted places.

\section{Types of polluted places according sector of activity}

As a result of the analysis, it can be concluded that a large part of the territory of 1st category (polluted place) both in cities of republican significance and districts is registered by one or two to a code of sector of activity. It gives evidence, that there is a relatively large diversity of sectors of activity. For example, main activities promoting pollution in cities of republican significance are production of various industrial products, such as chemicals, their products, paints, drying oils, etc., production of construction products, as well as works on maintenance and repair of automobiles, fuel marketing, waste management, various types of transport management, etc. However, the most part of polluted places in cities have been developed in connection with the retail sale of fuel and wholesale of solid, liquid and gaseous fuels, as well as waste management (Table 3).

Also outside of the cities, mainly in rural area, as sectors of activity prevail automotive fuel retail, waste management, territory cleaning, as well as forestry and timber preparation services, crop production, vegetable growing, gardening (Table 3).

Table 3. Breakdown of polluted places according to main sectors of activity

\begin{tabular}{|c|c|c|c|c|c|}
\hline \multirow[b]{2}{*}{ Code } & \multirow[b]{2}{*}{ Sector of activity } & \multicolumn{2}{|c|}{ Cities of republican significance } & \multicolumn{2}{|c|}{ Districts } \\
\hline & & number & $\begin{array}{c}\% \text { of total } \\
\text { number }\end{array}$ & number & $\begin{array}{c}\% \text { of total } \\
\text { number }\end{array}$ \\
\hline 0110 & Crop production, vegetable growing, horticulture & 1 & 0.8 & 4 & 3.2 \\
\hline 0202 & Forestry and logging services & - & - & 5 & 4.0 \\
\hline 2320 & Manufacture of refined petroleum products & 7 & 5.5 & 2 & 1.6 \\
\hline 3510 & Construction and repair of ships and boats & 5 & 3.9 & - & - \\
\hline 4030 & Steam and hot water supply & 7 & 5.5 & 7 & 5.6 \\
\hline 5020 & Car maintenance and repair & 5 & 3.9 & - & - \\
\hline 5050 & Automotive fuel retail & 20 & 15.7 & 46 & 37.1 \\
\hline 5151 & $\begin{array}{l}\text { Wholesale of solid, liquid and gaseous fuels and related } \\
\text { products }\end{array}$ & 18 & 14.2 & 12 & 9.7 \\
\hline 6010 & Rail transport & 6 & 4.7 & 1 & 0.8 \\
\hline 6110 & Sea and coastal water transport & 3 & 2.4 & - & - \\
\hline 6311 & Cargo loading and unloading & 6 & 4.7 & - & - \\
\hline 9000 & Waste management, territory cleaning & 8 & 6.3 & 28 & 22.6 \\
\hline 9001 & Collection and treatment of sewage & 2 & 1.6 & 1 & 0.8 \\
\hline \multirow[t]{2}{*}{9002} & Waste collection and treatment & 5 & 3.9 & - & - \\
\hline & Total & 93 & 73.2 & 106 & 85.5 \\
\hline \multicolumn{2}{|c|}{ Sum total } & 127 & 100.0 & 124 & $\mathbf{1 0 0 . 0}$ \\
\hline
\end{tabular}

In turn, in districts the list of sectors of activity promoting pollution is not so wide. It is shown by the fact that more than $80 \%$ of all polluted places have been developed as a result of the activities or inactivity of some of the companies representing the abovementioned operating sectors.

The survey established a fact that owners of polluted places both in cities and districts, mostly are legal persons. In cities they are more than $60 \%$, and in districts $-45 \%$. In rural area large part $(35 \%)$ of the registered polluted places also is municipal ownership, only small proportion of ownership with polluted places belongs to natural persons or to the state.

Types of potentially polluted places according sector of activity 
Summarizing data on potentially polluted places by their sectors of activity, it can be concluded that in urban area the status of the potentially polluted place mostly is allocated to areas of activities of such industries as retail automotive fuel, car maintenance and repair, steam and hot water supply, wholesale of solid, liquid and gaseous fuels and related products, as well as waste management, rail transport, etc. They make more than half of the types of sectors of activity mentioned in the Register, which contribute to determining the status of a potentially polluted place. The other half consists of a large number of different activities which are mentioned in the Register only once or twice as the basis for determining the status of potentially polluted place. This indicates the great diversity of potentially polluted places and the fact that practically in each sector of activity, disregarding occupational safety and specific industry conditions and requirements, can arise appropriate pollution conditions.

The largest number of potentially polluted places included in the Register is located rural area of Latvia. Like in urban area, there the biggest proportion is made up of gas stations, sector of activity of which is automotive fuel retail. The second biggest group of potentially polluted places consists of areas with activity in the field of plant growing, vegetable growing and horticulture. They are territories containing mineral fertilizers, chemicals and pesticide warehouses. An important risk factor for pollution are livestock farms (cattle breeding, dairy farming, pig farming) and general operation of public services, which are military objects, mainly the territory of the former USSR army (Table 4).

Table 4. Breakdown of potentially polluted places according main sectors of activity

\begin{tabular}{|c|c|c|c|c|c|}
\hline \multirow{2}{*}{ Code } & \multirow{2}{*}{ Sector of activity } & \multicolumn{2}{|c|}{$\begin{array}{l}\text { Cities of republican } \\
\text { significance }\end{array}$} & \multicolumn{2}{|c|}{ Districts } \\
\hline & & number & $\begin{array}{c}\% \text { of total } \\
\text { number }\end{array}$ & number & $\begin{array}{c}\% \text { of total } \\
\text { number }\end{array}$ \\
\hline 0110 & Crop production, vegetable growing, horticulture & - & - & 388 & 17.2 \\
\hline 0121 & Cattle breeding, dairy cattle breeding & - & - & 131 & 5.8 \\
\hline 0123 & Pig farming & - & - & 74 & 3.3 \\
\hline 4030 & Steam and hot water supply & 46 & 11.6 & 133 & 5.9 \\
\hline 5020 & Car maintenance and repair & 22 & 6.1 & 163 & 7.2 \\
\hline 5050 & Automotive fuel retail & 55 & 15.3 & 411 & 18.2 \\
\hline 5151 & $\begin{array}{l}\text { Wholesale of solid, liquid and gaseous fuels and related } \\
\text { products }\end{array}$ & 26 & 7.2 & 147 & 6.5 \\
\hline 6010 & Rail transport & 13 & 3.6 & 9 & 0.4 \\
\hline 7511 & General government service activities & 18 & 5.0 & 349 & 15.5 \\
\hline 9000 & Waste management, territory cleaning & 16 & 4.5 & - & - \\
\hline \multirow[t]{2}{*}{9001} & Collection and treatment of sewage & 10 & 2.8 & - & - \\
\hline & - & 206 & 52.1 & 1805 & 80.1 \\
\hline & Sum total & & 100.0 & 2253 & $\mathbf{1 0 0 . 0}$ \\
\hline
\end{tabular}

Performing the analysis of ownership situation of potentially polluted places, it can be concluded that in urban area they mainly are owned by legal persons, while in rural area they are owned by legal and natural persons, and municipalities. Only small part of them is owned by the state.

\section{MAIN CONCLUSIONS}

The analysis of the data included in the Register of polluted and potentially polluted places indicates that development of entrepreneurship, concentration of the population promotes increase of the number of polluted and potentially polluted places. This is also evidenced by the fact that in urban area most part of polluted places is owned by legal persons - different companies.

Main sectors of activity promoting development of polluted places both in urban and rural area are retail of automotive fuel, wholesale of solid, liquid and gaseous fuels and waste management. Main sectors of activity determining the status of polluted place in urban area are automotive fuel retail and steam and hot water supply, while in rural area automotive fuel retail, crop production, vegetable growing, horticulture and general government services. Consequently, objects promoting pollution are gas stations, non-cultivated waste dumps and in rural areas also mineral fertilizers, chemicals and pesticide warehouses, as well as former military objects.

All polluted places can also be considered as degraded territories because they contain pollutants. On the other hand, the question whether the potentially polluted places can be attributed to degraded territories remains controversial. Because the status of potentially polluted place is given after unconfirmed information, it may not contain pollutants; therefore it may not be degraded territory.

\section{REFERENCES}

1. Akhtar-Schuster M., Stringer L.C. , Erlevein A., Metternich G., Minelli, S., Safriel, U., Sommer, S.2017. Unpacking the concept of land degradation neutrality and addressing its operation through the Rio Conventions. Journal of Environmental Management, Vol. 195, pp. 4-15. https://doi.org/10.1016/j.jenvman.2016.09.044

2. Degradeto teritoriju izpete Rīgas pilsētā. 2004. Pētniecības darbs. Atskaite. SIA “Grupa 93”, Rīgas Domes Pilsētas attīstības departaments, Rīga. 66 lpp. [In Latvian] 
3. Hajdu, F., Penje, O., Fischer, K. 2016. Questioning the use of 'degradation' in climate mitigation: A case study of a forest carbon CDM project in Uganda. Land Use Policy, Vol. 59, pp. 412-422. https://doi.org/10.1016/j.landusepol.2016.09.016

4. Jackson, J.B., Finka, M., Hermann, G., Kliučininkas, L., Lemešenoka, N., Petriková, D., Pletnická, J., Teirumnieks, E., Velykienė, D., Vojvodíková, B., Zahnašová, M., Zubková, M. 2010. Degradētās teritorijas. Rokasgrāmata. Starpdisciplinārs mācību līdzeklis degradēto teritoriju atjaunošanai. Mācību līdzeklis Latvijai un Lietuvai. VŠB-Ostravas Tehniskās universitātes Būvniecības fakultāte, Ostrava. 140 lpp. [In Latvian]

5. Jankauskas, B., Jankauskiene, G. 2003. Erosion-preventive crop rotations for landscape ecological stability in upland regions of Lithuania. Agriculture. Ecosystems \& Environment. Available at: http://www.sciencedirect.com/science/article/pii/S0167880902001007 (Accessed on 24/10/2017).

6. Jankava, A., Parsova, V., Berzina, M., Didrihsone, D., Platonova, D., Palabinska, A. 2017. Assessment of land degradation for sustainable development of municipality territories. Economic Science for Rural Development, Proccedings of the International scientific conference, pp. 69 - 75. Jelgava: LUA.

7. Juozapavičiūte, K. 2016. Mokslininkai: pastaraisiais metais stebima ryški Lietuvos dirvožemio degradacija. Žalioji Lietuva. Available at: http://www.delfi.lt/grynas/aplinka/mokslininkai-pastaraisiais-metais-stebima-ryski-lietuvos-dirvozemiodegradacija.d?id=59214483 [In Lithuanian].

8. Karklins, A., Lipenite, I., Ruza, A. 2016. Plant - available soil nitrogen - estimates and interpretations. $5^{\text {th }}$ EUROSOIL international congress, Istambul, Turkey, p. 302.

9. Kronenberg, M., Trably, E., Bernet, N., Paturean, D. 2017. Biodegradation of polycyclic aromatic hydrocarbons: Using microbial bioelectrochemical systems to overcome an impasse. Environmental Pollution, Vol. 231, Part 1, pp. $509-523$. https://doi.org/10.1016/j.envpol.2017.08.048

10. Law On Administrative Territories and Populated Areas: Law of Republic of Latvia 2008. Available at: https://likumi.lv/doc.php?id=185993 (Accessed on 02/11/2017).

11. On pollution: Law of Republic of Latvia 2001. Available at: https://likumi.lv/doc.php?id=6075 (Accessed on 02/11/2017)

12. Parsova, V., Jankava, A., Kukule, I. 2017. Determination of Land Degradation for Sustainable Development of Municipality Territories. "Geomatics 2017” Baltic Geodetic Congress, proceedings. Gdansk University of Technology, Gdansk, pp. 158 - 162. https://doi.org/10.1109/BGC.Geomatics.2017.63

13. Salvati, L., Carlucci, M. 2014. Zero Net Land Degradation in Italy: The role of socioeconomic and agro-forest factors. Journal of Environmental Management, Vol. 145, pp. 299-306. https://doi.org/10.1016/j.jenvman.2014.07.006

14. Transforming our world: the 2030 Agenda for Sustainable Development. Available at: https://sustainabledevelopment.un.org/post2015/transformingourworld. (Accessed on 24/10/2017). 